\title{
PARADIGMA THOMAS KUHN DAN RELEVANSINYA TERHADAP PERKEMBANGAN PEMIKIRAN ISLAM DI INDONESIA
}

\author{
Oleh: \\ Taufik Rahman * \\ Universitas Islam Negeri Sunan Kalijaga Yogyakarta \\ Taufiqareroa1@gmail.com
}

\begin{abstract}
Paradigm has an important in science. According to Kuhn, the paradigm is very influential on the steps and results of research. Because a paradigm is a pattern or framework of thinking adopted by scientists in conducting research. This article will explain Thomas Kuhn's paradigm and its relevance toward Islamic thought in Indonesia. This article is library research using a historicalphilosophical approach. The historical-philosophical approach use to see the development of Islamic thought in Indonesia and analyze or find the relevance of Thomas Kuhn's paradigm concept toward the development of Islamic thought in Indonesia. The results show that the paradigm concept of Thomas Kuhn can be used in Islamic scholarship in Indonesia to produce Islamic thought that is relevant to current issues.
\end{abstract}

Keywords: Paradigm, Relevance, Islamic Thought, Indonesia

\section{A. PENDAHULUAN}

Peradaban modern yang lahir dari rahim renaisans memang telah melahirkan ilmu pengetahuan dan teknologi yang canggih. Bahkan barangkali telah melampaui batas hayal manusia (manusia sebelum perdaban modern). Melalui dalil-dalil obyektivisme, peradaban modern dengan corak positivistiknya yang menempatkan kebenaran dalam radius indrawi (Maarif, 2019a, p. 132) telah mampu mengalahkan lawan-lawannya di Barat (agama, mitos, dan pemikiran/pandangan lainnya yang dalil kebenarannya tidak mampu diverifikasi) atau setidaktidaknya mampu membuatnya menyingkir dari arena pertarungan gagasan di gelanggang intelektual.
Namun demikian, objektifitas yang diagungkan oleh sains modern selama ini ternyata tak sepenuhnya bisa melepaskan diri dari yang namanya subjektivitas atau konsensus dari masyarakat sains itu sendiri.

Adalah Thomas Kuhn seorang filosof abad ke-20 yang mengatakan bahwa sains tak bisa melepaskan diri dari paradigma. Di mana paradigma yang dimaksud adalah teori atau cara pandang yang disepakati bersama dalam masyarakat sains, ilmuwan (Kuhn, 1977,p.294) Pemikirannya tentang paradigma dan revolusi sains (pergeseran paradigma) telah memberikan sumbangsih yang cukup besar dalam perkembangan filsafat, khususnya dalam filsafat ilmu. Thomas Kuhn, sebagai seorang 
pemikir telah mampu mendobrak pemikir pendahulunya, Auguste Comte, yang bercorak positivistik: Di mana perkembangan ilmu pengetahuan dinilai melalui proses verifikasi dan merupakan hasil kumulatif dari teori dan riset sebelumnya.

Berpijak pada sejarah ilmu, Thomas Kuhn justru melihat perkembangan suatu ilmu tidak bersifat kumulatif atau evolutif, melainkan melalui revolusi sains (pergeseran paradigma). Di mana suatu paradigma lama ditinggalkan diganti dengan paradigma baru yang lebih memadai dalam menjawab persoalan - sebagaimana yang terjadi dalam sejarah ilmu, yaitu revolusi Copernicus: pergeseran paradigma geosentrisme (bumi sebagai pusat alam semesta) beralih ke paradigma heliosentrisme (matahari sebagai pusat alam semesta) (Kuhn, 1957, p. 1)

Konsep paradigma dan revolusi sains yang ditawarkan oleh Thomas Kuhn ini sangat penting dalam bidang keilmuan secara umum, tidak hanya dalam ranah sains atau alam. Karena selain paradigma sangat mempengaruhi terhadap langkahlangkah dan hasil dari suatu penelitian, ia juga membuat ilmu semakin berkembangan dengan adanya pergeseran paradigma lahirnya paradigma baru yang mampu menjawab persoalan-persoalan yang tidak mampu diselesaikan oleh paradigma yang ada sebelumnya.

Thomas Kuhn sebagai pemikir besar telah menarik banyak minat para sarjana atau peneliti untuk mengkaji pemikirannya. Sejauh ini, kajian mengenai Kuhn cenderung mengkaji dua aspek. Pertama, kajian mengenai hubungan paradigma Kuhn dan ilmu pengetahuan umum (Asrudin, 2017; Sudrajat et al., 2019; Alifah Putri and Iskandar, 2020) Kecenderungan kedua ialah kajian mengenai paradigma dan ilmu Islam (Ulya, Inayatul dan Nushan, 2015; Effendi, 2020) Sebagaimana dikatakan Effendi, paradigma Kuhn hendak menyadarkan para ilmuwan dan cendikiwan baik umum maupun Muslim untuk mengkaji ulang teoriteori yang ada (Effendi, 2020, p. 57.) Dari dua kecenderungan kajian tersebut, aspek relevansi dari paradigma Thomas Kuhn terhadap perkembangan pemikiran Islam di Indonesia tidak banyak diperhatikan. Padahal, Indonesia merupakan salah satu negara dengan penduduk Muslim terbesar di dunia.

Tujuan tulisan ini adalah melengkapi kekurangan kajian yang ada sebelumnya dengan cara memetakan konsep paradigma Thomas Kuhn dan menjelaskan relevansinya terhadap perkembangan pemikiran Islam di Indonesia.

\section{B. METODE PENELITIAN}

Penelitian ini merupakan penelitian kepustakaan (library research) yaitu penelitian yang menggunakan kepustakaan baik berbentuk buku, artikel, dan sejenisnya. Adapun sumber dari penelitian ini ada dua, yaitu sumber primer dan skunder.

Sumber primer dari penelitian ini adalah karya Thomas Kuhn yang 
berjudul The Structure of Scientific Revolution. Sedangkan untuk sumber skundernya adalah literatur sejenis yang berkaitan dengan topik penelitian.

Adapun langkah yang dilakukan dalam mengolah data penelitian ini meliputi beberapa tahap. Yang pertama, mengklasifikasi pemikiranpemikiran Thomas Kuhn yang berkaitan dengan paradigma. Kedua, mengumpulkan bahan-bahan yang berkaitan dengan pemikiran Islam di Indonesia yang ada kaitannya dengan paradigma. Kemudian yang ketiga, dilanjutkan dengan mencari relevansinya dari teori-teori Thomas Kuhn terhadap perkembangan pemikiran Islam di Indonesia.

\section{PEMBAHASAN}

\section{Biografi Singkat Thomas Kuhn dan Karyanya}

Thomas Kuhn lahir di Cincinnati, Ohio Amerika Serikat pada 18 juli 1922. Pada tahun 1949 ia memperoleh gelar Ph.D dalam bidang ilmu fisika di Harvad University. Di tempat yang sama ia bekerja sebagai asisten dosen dalam bidang pendidikan umum dan sejarah ilmu. Tujuh tahun kemudian tepatnya pada 1956, Kuhn menerima tawaran kerja di Universitas California, Barkeley, sebagai dosen dalam bidang sejarah sains. Tahun 1964, Kuhn mendapat anugrah gelar Guru Besar (profesor) dari Princeton University dalam bidang filsafat dan sejarah sains. Selanjutnya pada tahun 1983 ia dianugrahi gelar profesor lagi dari Massachuasetts Institute of University. Di masa-masa akhir hidupnya Kuhn menderita penyakit kanker selama bebarapa tahun yang akhirnya meninggal dunia pada tahun 1996 di usia 73 (Muslih, 2004, p. 127)

Karya Thomas Kuhn yang fenomenal adalah The Structure of Scientific Revolution (1962) dan Essential Tension: Selected Studies in Scientific Traditional and Change (1977). Karya yang monumental dari Kuhn adalah karya yang pertama tetang sejarah dan filsafat ilmu pengetahuan dengan konsep dan teori besarnya yang terkanal tentang paradigma dan revolusi sains. Karya Kuhn tersebut lahir ketika ia hampir menyelesaikan disertasinya dalam bidang fisika teoritias. Pengalaman dalam ilmu fisika membawa Kuhn pada suatu kesimpulan bahwa teori dan praktek ilmiah telah usang, sehingga secara radikal telah merobohkan konsepsi dasarnya tentang sifat ilmu pengetahuan. Buku itu sempat terjual lebih dari satu juta copy dalam 16 bahasa (Muslih, 2004, p. 162)

Melalui karyanya yang monumental The Structure of Scientific Revolution (1962), Kuhn tumbuh menjadi sosok pemikir yang berpengaruh besar terhadap kaum akademik dan ilmuwan pada umumnya di kelas dunia, khusunya terkait dengan teori "pergeseran paradigma". Konsep ini menjadi idiom kunci dalam literatur akademik sampai ke Inggris untuk konteks perkembangan ilmu di akhir abad 20 bahkan sampai awal abad ke-21 (Sumarna, 2016, pp. 37-38) 


\section{Peran Sejarah dalam Pemikiran Thomas Kuhn}

\begin{abstract}
Dalam sejarah perkembangan ilmu pengetahuan, paradigma positivistik telah menghegemoni begitu lama. Namun sekitar tiga dasawarsa terakhir ini, terlihat perkembangan baru dalam sejarah filsafat ilmu pengetahuan. Perkembangan ini sebagai upaya pendobrakan atas paradigma positivistik yang dipelopori oleh tokoh-tokoh seperti Thomas Kuhn, Paul Feyerabend dan kawan-kawan (Zubaedi, 2007, p. 198)
\end{abstract}

Sejarah ilmu merupakan starting point dan kacamata utama bagi Thomas Kuhn dalam menyoroti permasalahan-permasalahan

fundamental dalam epistemologi yang selama ini menjadi teka-teki. Sejarah, bagi Kuhn bukanlah sebatas anekdot atau kronologi dari pristiwa masa lampau, tetapi merupakan khazanah yang sangat kaya yang dapat mempengaruhi transformasi citra sains dalam perkembangannnya.(Kuhn, 1970, p. 1) Ia menegaskan bahwa sains pada dasarnya lebih dicirikan oleh paradigma dan revolusi yang menyertainya(Zubaedi, 2007, p. 199) Kuhn menjumpai revolusi yang terjadi berkali-kali pada sejarah ilmu pengetahuan, yaitu kejadian di mana suatu paradigma yang baru mengganti paradigma ilmu pengetahuan sebelumnya (Latif, 2014, p. 220)

Pergeseran paradigma dalam sains merupakan sesuatu yang niscaya karena adanya temuantemuan baru yang mungkin bertentangan dan tidak bisa dijawab oleh paradigma lama. Banyak contoh dari pergeseran paradigma ini, kita bisa melihat dari sejarah ilmu yang ada, misalnya dalam bidang fisika yang berkaitan dengan teori cahaya. Mula-mula cahaya dinyatakan sebagai foton, yaitu maujud mekanis kuantum yang memperlihatkan beberapa karakteristik gelombang dan partikel. Teori ini berumur setengah abad sebagai landasan riset sebelum akhirnya muncul teori Newton menggantikannya. Teori baru Newton mengatakan bahwa cahaya merupakan partikel yang sangat halus. Teori dari Newton ini juga diterima oleh hampir semua praktisi sains optika, sampai muncul teori baru yang dianggap lebih baik yang digagas oleh Young dan Frensel awal abad 19 yang selanjutnya dikembangkan oleh Einstein, yaitu bahwa cahaya merupakan gerakan gelombang tranversal (Zubaedi, 2007, p. 203)

Sejarah ilmu yang semula praktis menjadi semacam upaya untuk melihat urutan kronologis dari prestasi-prestasi ilmiah individual menjadi semakin ketat, teliti, sehingga dari sini semakin banyak menemukan fakta bahwa sejarah berperan penting terhadap perkembangan suatu ilmu. Dari sejarah itulah belajar bagaimana suatu ilmu berkembang, bergesernya suatu paradigma ke paradigma yang lain, dan seterusnya. Karena saking antusiasnya terhadap kesadaran akan pentingnya sejarah ilmu, Thomas Kuhn menganjurkan sebaiknya filsafat ilmu berguru kepada sejarah ilmu (Zubaedi, 2007, p. 200) 


\section{Konsep Paradigma/Normal Sains Thomas Kuhn}

Paradigma dalam kamus Oxford English Dictionary diartikan sebagai patern (pola) atau example (contoh). Bagi Thomas Kuhn, paradigma merupakan pola yang diikuti oleh pemikir ketika ia menjelaskan pandangan-pandanganya. Aspek kunci dari paradigma yaitu bagaimana menghadapi masalah dan bagaimana menyelesaikannya (Latif, 2014, p. 220)

Thomas Kuhn menggunakan istilah "paradigma" untuk menggambarkan sistem keyakinan yang mendasari upaya pemecahan teka-teki di dalam ilmu. Dengan istilah paradigma ia bertujuan untuk mengajukan sejumlah contoh yang telah diterima tentang praktek ilmiah nyata, termasuk di dalamnya hukum, teori, aplikasi, instrumentasi, yang menyediakan model-model, yang menjadi sumber konsistensi dari tradisi riset ilmiah (Muslih, 2004, p. 127)

Paradigma Thomas Kuhn berusaha mendobrak dunia sains untuk menginterpretasi ulang perkembangan sejarahnya. Dalam pandangan Kuhn, sains bukanlah suatu pergerakan sinambung dari sains normal (normal science), melainkan sebuah lompatan paradigma sebagai akibat dari revolusi sains. Maka dunia sains merupakan perkembangan sains yang bergerak dari paradigma lama menuju paradigma baru. Paradigma Kuhn membuka wawasan untuk melihat sains sebagai teori yang berkembang dan berubah, tergantung paradigma yang mendasarinya (Latif, 2014, p. 2018)

Paradigma bisa juga dipahami sebagai pandangan dunia (word view), cara pandang umum (general perspective), atau cara menguraikan kompleksitas (way of breaking down the complexity). Secara sederhana paradigma bisa dimaknai semacam seperangkat asumsi-asumsi teori umum dan hukum-hukum serta teknik-teknik aplikasi yang dianut secara bersama oleh para anggota suatu masyarakat ilmiah (Nurkhalis, 2012, p. 96). Komunitas ilmiah bukan berarti sekumpulan ilmuwan yang bekerja dalam suatu tempat. Melainkan suatu komunitas yang memiliki suatu paradigma bersama tentang alam ilmiah, nilai-nilai, asumsi-asumsi, tujuan, norma dan kepercayaan-kepercaya (Muslih, 2004 , p. 128) Paradigma mempunyai peran penting dan vital dalam masyarat sains dan perkembangan ilmu pengetahuan karena ia sebagai pola atau cara pandang yang menentukan hasil dari suatu riset ilmiah.

Menurut Kuhn, paradigma ilmu adalah suatu kerangka teoritis, atau suatu cara memandang dan memahami alam, yang telah disepakati dan digunakan oleh sekelompok ilmuwan sebagai pandangan dunianya (word view). Paradigma berfungsi sebagai lensa yang dengannya ilmuwan dapat mengamati dan memahami serta menemukan jawaban terhadap masalah-masalah ilmiah dalam bidang masing-masing (Muslih, 2004, p. 128) Paradigma ialah apa yang dimiliki bersama oleh angotaanggota suatu masyarakat sains, 
sedangkan masyarakat sains merupakan kumpulan orang-orang yang memiliki suatu paradigma bersama (Kuhn, 1970, p. 176)

Penggunaan paradigma dalam meniliti sains merupakan kondisi normal sains. Pada keadaan normal sains, para ilmuwan berkesempatan menjabarkan dan mengembangkannya secara teperinci dan mendalam, namun tidak kritis terhadap paradigma yang membimbing aktivitas ilmiahnya, dan selama menjalankan riset ini, ilmuwan bisa saja menjumpai berbagai fenomena yang tidak bisa dijawab dengan teorinya, paradigma (Mustansyir and Munir, 2013, p. 154) Inilah yang disebut dengan anomali.

Paradigma memperoleh kedudukan di masyarakat ilmiah karena lebih berhasil daripada saingannya dalam memecahkan beberapa masalah yang mulai diakui oleh kelompok praktisi. Namun, untuk berhasil bukan harus dengan sempurna dalam menangani suatu masalah. Keberhasilan sebuah paradigma semisal, Aristoteles tentang Gerak, perhitungan Ptolemeaus tentang kedudukan planet (matahari mengelilingi bumi) (Kuhn, 1970 , p. 23) bukan karena ia benar atau sempurna, tapi karena lebih disepakati oleh sekelompok ilmuwan pada waktu itu. Dalam perkembangan selanjutnya, secara dramatis, ketidakberhasilan Ptolemeus betulbetul terungkap ketika muncul paradigma baru dari Copernicus yang dikenal dengan teori Heliosentris (bumi mengelilingi matahari). Dalam hal ini terjadi pergeseran paradigma dari geosentris ke heliosentris. Apa yang diungkapkan Copernicus (heliosentris) sebenarnya sudah pernah diungkapkan oleh Aristarchus pada zaman Yunani Kuno, namun pandangan Aristarchus ini tenggelam dan tidak diakui karena masyarakat lebih menerima pandangan Ptolemeaus yang dikenal dengan teori geosentris, bahwa bumi sebagai pusat alam semesta dan matahari serta planet lain mengelilingi bumi (Ulya, Inayatul dan Nushan, 2015, p. 266)

\section{Pergeseran Paradigma dan Tahapan-tahapanya}

Revolusi sains (pergeseran paradigma) merupakan suatu gambaran dari pergeseran atau lompatan paradigma lama ke paradigma baru. Terjadinya revolusi sains dimulai dengan adanya anomali-anomali yang semakin menumpuk dan tidak bisa dijawab oleh paradigma sebelumnya. Munculnya paradigma baru sebagai upaya menjawab persoalan-persoalan yang ada. Jika paradigma diterima oleh masyarakat sains, maka revolusi sains dapat terwujud (Zubaedi, 2007, p. 205) Meskipun paradigma merupakan hasil dari sebuah kesepakatan, bukan berarti setiap paradigma bisa dipakai asal disepakati, namun sebuah paradigma bisa diterima biasanya kalau ia bersifat umum yang memungkinkan untuk membuahkan hasil dalam memberikan kerangka umum untuk penelitian selanjutnya.

Revolusi sains merupakan episode perkembangan non-komulatif yang di dalamnya paradigma lama diganti seluruhnya dengan paradigma yang baru. Bahwa paradigma yang 
ada tidak lagi berfungi secara memadai dalam eksplorasi suatu aspek dari alam, yang sebelumnya paradigma itu sendiri yang menunjukkan jalan bagi eksplorasi itu (Kuhn, 1970, p. 91) Ketidakmampuan paradigma lama dalam menjawab gejala yang ada atau terjadinya malafungsi dapat menyebabkan krisis yang berujung pada revolusi. Untuk lebih jelasnya bisa kita lihat tahapan-tahapan di bawah ini:

\section{a) Tahap Pra Paradigma}

Pada tahap pra paradigma ini aktivitas ilmiah dilakukan secara terpisah dan tidak terorganisir. Hal demikian dilakukan karena belum adanya kesepakatan antar ilmuwan dalam masyarakat sains. Belum adanya pola atau skema umum yang bisa menyatukan teori masing-masing dari ilmuwan. Pada tahap ini bisa dikatakan juga sebagai tahap pertarung teori-teori yang ada untuk menjadi suatu paradigma.

Tahap ini berlangsung selama kurun tertentu sampai ditemukannya pola umum atau paradigma yang disepakati oleh kalangan ilmuwan. Dan ketika satu paradigma mulai disepakati, maka jalan menuju normal sains sudah ditemukan.

\section{b) Paradigma/ Normal Sains}

Pada tahap paradigma/ normal sains ini aktivitas ilmiah sudah tersusun dan terorganisir dengan adanya satu paradigma yang disepakati. Komunitas ilmiah menafsirkan alam ilmiah melalui paradigma ilmiahnya. Kondisi sains normal ini merupakan usaha sungguh-sungguh dari ilmuwan untuk menundukkan alam ke dalam kotak konseptual yang disediakan paradigma (Muslih, 2004, p. 130) Pada tahap ini ilmuwan sudah punya rumusan tentang apa yang harus diteliti dan diamati, bagaimana menyusun pertanyaan-pertanyaan, bagaimana menjawab pertanyaanpertanyaan yang ada dan seterusnya.

\section{c) Anomali}

Anomali merupakan gambaran dari kondisi di mana persoalanpersoalan baru muncul dan paradigma yang ada tak mampu menjawabnya. Suatu teori sudah tidak sesuai dengan realitas, munculnya keganjilan-keganjilan, ketidaktepatan, penyimpanganpenyimpangan dan temuan-temuan baru yang berbeda.

\section{d) Krisis}

Krisis merupakan tahap di mana semakin banyaknya anomali/ persoalan-persoalam yang tidak bisa dijawab oleh paradigma lama. Adanya kesadaran terhadap anomali membuat ilmuwan mempertanyakan paradigma yang dipakainya. Temuantemuan fakta baru yang tidak cocok dengan paradigma lama mendorong para ilmuwan untuk merumuskan suatu paradigma baru.

\section{e) Revolusi Sains}

Lahirnya krisis yang disebabkan oleh anomali-anomali yang ada dan munculnya teori atau paradigma baru inilah yang melahirkan revolusi sains. Revolusi sains dimaknai sebagai pergeseran dari paradigma lama 
menuju paradigma yang baru. Paradigma baru diterima untuk menjawab persoalan yang tidak bisa dijawab oleh paradigma sebelumnya. Revolusi terjadi karena adanya perspesi ilmuwan terhadap kekurangan paradigma lama yang dianutnya dalam memecahkan realitas alam (Latif, 2014, p. 139) Ilmu pengetahuan terus berkembang semacam ini, di mana paradigma baru bila sampai pada waktunya juga diganti dengan paradigma yang lebih baru dan cocok untuk melihat dan menjawab persoalan yang ada.

Pergeseran paradigma/revolusi akan selalu ada dalam perkembangan ilmu pengetahuan karena ilmu bergerak ke arah yang lebih baik. Perkembangan ini bisa kita lihat misalnya, dalam perkembangan awal filsafat di Yunani klasik menggunakan paradigma kosmologis di mana kajiannya lebih menfokuskan pada alam. Dari paradigma ini lahir pemikir seperti Thales, Anaximandros, Anaximenes, dan Herakleitos. Keempat filsuf memberikan jawaban yang berbeda tentang asas dari alam semesta: Thales menyatakan unsur dasar dari alam semesta ini adalah air. Anaximandros mengatakan "yang tak terbatas" (to eperion). Anaximenes mengatakan udara. Herakleitos mengatakan api (Bertens, 2017, p. 9) Pada abad pertengahan paradigmanya bergeser ke paradigma teosentris, fokus kajian secara umum lebih menitikberatkan pada persoalan Tuhan atau agama, sehingga lahir sekolah Kristen yang diberi nama Mazhab Alexandria dengan upaya melahirkan suatu teologi ilmiah dengan menggunakan unsur-unsur filsafat Yunani (Bertens, 2017, p. 20). Kemudian bergeser lagi pada abad modern, paradigma yang digunakan ialah antroposentris (tokoh utamanya Descartes yang dijuluki sebagi "bapak filsuf modern" melalui rasionalismenya) menjadikan manusia sebagai titik sentral kajiannya dan seterusnya. Melihat dari sejarah yang ada, setidaknya ada hal yang perlu digaris bawahi bahwa suatu paradigma bersifat sementara dan relatif. Kesadaran atas relatifnya suatu paradigma sangat penting dalam perkembangan ilmu-ilmu, khususnya dalam keilmuan Islam. Hal yang demikian sangat diperlukan untuk menjawab problem kehidupan yang terus berubah dan berkembang.

\section{Relevansi Paradigma Thomas Kuhn terhadap Perkembangan Pemikiran Islam di Indonesia}

Sebelum membahas lebih jauh mengenai relevansi pemikiran Thomas Kuhn ini, penulis perlu menegaskan bahwa pada hakikatnya Kuhn tidak berbicara keilmuan dalam ranah keagamaan, namun dalam sains. Lalu dalam arti apa relevansi yang dimaksud dalam tulisan ini? Maksudnya adalah kerangka berpikir Thomas Kuhn yang berdasarkan sejarah itu serta munculnya berbagai anomali dan rovolusi paradigmanya yang bisa kita aplikasikan atau dijadikan sebagai titik acuan bahwa produk pemikiran atau keilmuan itu sifatnya tidak statis. Akan tetapi, berjalan dengan pergulatan sengit antar berbagai pemikiran untuk menjadi yang paling memadai menjawab persoalan-persoalan. Dalam hal ini, pemikiran Kuhn 
menemukan relevansinya sebagai kerangka berpikir dalam melihat dan merumuskan pemikiran kegamaan (pemikiran Islam) yang sejatinya juga tidak pernah tunggal. Lain dari itu, pemikiran keagamaan juga tidak bisa melepaskan diri dari persoalan zaman yang dihadapi. Dengan kata lain, segala produk pemikiran dalam keilmuan Islam (politik, tafsir, fiqih, dll) sejatinya merupakan jawaban terhadap persoalan zamannya yang dihadapi oleh pemikir atau penulis keilmuan Islam tersebut. Jadi, bukan hal yang aneh jika kemudian produk pemikirannya tidak relevan lagi dalam konteks kekinian. Oleh karena itu, perlu dirumuskan ulang (ketika produk pemikiran yang dihasilkan oleh paradigma lama tidak memadai menjawab persoalan yang ada) agar supaya Islam bisa berdialog dan punya jawaban yang lebih relevan terhadap persolan-persoalan mutakhir.

Indonesia merupakan negara dengan penduduk mayoritas Muslim - al-Quran dan hadis menjadi pedoman utama dalam merumuskan keilmuan Islam untuk memberi jawaban terhadap persoalan agama dan kebangsaan, maka teori paradigma Thomas Kuhn dapat diaplikasikan sebagai berikut:

Pertama, sebelum terbentuk paradigma yang terjadi adalah pertarungan gagasan. Di mana berbagai gagasan bertarung untuk menjadi paradigma atau kerangka berpikir dalam melihat dan merumuskan persoalan. Artinya, sebelum ditemukan paradigma (yang disepakati) dalam memahami ajaranajaran Islam, al-Quran, Hadis, dan lain-lain, merupakan sesuatu yang wajar suatu gagasan dipertengkarkan untuk diuji mana yang paling memadai dalam menjawab persoalan yang ada.

Kedua, setelah pertarungan gagasan selesai dengan ditemukannya paradigma yang disepakati, maka dilanjutkan dengan mengkaji literatur-literatur keislaman - alQuran dan hadis khususnya - untuk memberikan jawaban terhadap persoalan umat yang semakin kompleks. Kondisi ini dalam teori Kuhn disebut sebagai normal sains.

Ketiga, konsep anomali yang digagas Kuhn bisa diposisikan dalam keilmuan Islam di Indonesia sebagai kondisi di mana pemikiran-pemikiran yang dihasilkan melalui paradigma lama tidak lagi relevan terhadap persoalan-persoalan yang ada. Artinya, perlu paradigma baru yang lebih memadai. Melalui konsep ini, secara tidak langsung pemikiran keagamaan bukanlah suatu pemikiran yang absolut, melainkan relatif dan temporal.

Keempat, pemikiran Thomas Kuhn tentang krisis. Dalam keilmuan Islam, krisis dapat kita posisikan sebagai kondisi di mana pemikiran Islam yang merupakan hasil dari produk paradigma lama tidak mampu menyelesaikan persoalan yang semakin kompleks dan banyak. Oleh karena itu, memerlukan paradigma atau cara baru dalam memahami ajaran Islam, seperti melakukan penafsiran ulang terhadap al-Quran dan Hadis yang hasilnya dapat menjadi solusi terhadap berbagai persoalan yang ada. 
Kelima, konsep revolusi sains Thomas Kuhn. Dalam keilmuan Islam, revolusi sains artinya menemukan dan menyepakati paradigma baru dalam memahami sumber ajaran Islam, al-Quran dan hadis, yang diyakini dapat melahirkan pemikiran Islam yang mampu menjawab persoalanpersoalan yang ada ketimbang paradigma sebelumnya.

Konsep paradigma dan revolusi yang digagas Kuhn sangat memberi inspirasi pada generasi ilmuwan selanjutnya untuk merumuskan kembali paradigma metodologi penelitiannya (Abdullah, 1996, p. 89) Terutama dalam membuka pola pikir ilmuwan Muslim, bahwa sesungguhnya dalam dinamika keilmuan itu kebenaran bersifat relatif, tidak ada kebenaran yang sifatnya mutlak, ia selalu terbuka dan memungkinkan lahirnya pengetahuan dan epistemologi keilmuan baru yang lebih mudah dan sesuai dengan kebutuhan zamannya. Dalam keilmuan Islam, al-Quran dan Hadis diyakini sebagai sumber kebenaran dan pedoman hidup. Tapi, apabila dalam perkembanganya muncul persoalan umat yang belum termaktup secara tegas dalam alQuran dan Hadis, maka ilmuwan Muslim hendaklah membuka diri terhadap metodologi baru dalam memahami Islam dengan tetap berpegang teguh pada nilai-nilai alQuran dan Hadis. Metodologi baru dalam Islam tidak hanya terpaku pada pendekatan normatif saja, banyak metodologi dan pendekatan yang bisa dipakai dalam menggali nilai-nilai alQuran Hadis dengan tujuan menjawab berbagai macam persoalan yang ada. Seperti pendekatan historis, sosiologis, antropologis dan lain sebagainya. Sehingga dengan bersikap terbuka dan menerima berbagai metode yang ada, kontribusi keilmuan Islam dapat berdialog dengan perubahan zaman dan bisa lebih mudah diterima (Ulya, Inayatul dan Nushan, 2015, p. 273)

Di Indonesia, beberapa contoh bagaimana suatu paradigma berpengaruh dalam keberagamaan seseorang atau bergesernya suatu paradigma lama ke paradigma baru bisa kita lihat pada tahun 70-an; isuisu pluralisme pada waktu itu dimunculkan ke publik oleh Gus Dur sebagai upaya menghargai perbedaan manusia, baik perbedaan karena agama, suku, ras dan lain sebagainya. Namun pada waktu itu, pandangan mengenai pluralisme tidak menjadi paradigma masyarakat Indonesia, sehingga paradigma pluralis tidak dipakai dan Gus Dur dicurigai. Namun beberapa tahun kemudian, dengan berkembangnya zaman dan bertambahnya wawasan masyarakat, masyarakat menyadari bahwa isu pluralisme yang dibawa Gus Dur adalah nilai luhur yang cocok dijadikan sebagai paradigma beragama agar tercipta kerukunan umat antar agama di Indonesia.

Contoh lain misalnya, seperti yang dikatakan oleh Buya Safi'i Ma'arif: dahulu masyarakat banyak yang menolak pembangunan rumah sakit hanya karena orang-orang Belanda waktu itu di Indonesia membuat rumah sakit. Penolakan mereka disandarkan pada hadis "barang siapa menyerupai suatu kaum maka dia termasuk 
golongannya." Paradigma mereka yang menolak adalah segala hal yang bukan dari Islam tidak boleh ditiru, termasuk rumah sakit yang dibangun oleh orang-orang Belanda di Indoensia kala itu. Namun demikian, pada akhirnya paradigma itu bergeser dengan adanya kesadaran baru dari sebagian besar kalangan masyarakat bahwa membuat rumah sakit seperti apa yang dilakukan orang-orang Belanda tidaklah haram karena pembangunan rumah sakit adalah untuk kemaslahatan umat Islam itu sendiri. Dan pada akhirnya saat ini kita bisa menyaksikan sudah berapa banyak rumah sakit Islam yang dibangun karena suatu paradigma, paradigma baru yang dulunya sempat dinggap sesat.

Perdebatan kaum modernis dengan kaum tradisionalis dalam sejarah keilmuan Islam di Indonesia bisa juga dijadikan contoh lain dalam hal ini. Misalnya mengenai taklid, kaum modernis (yang umumnya para pemikir muda) yang terinspirasi dari Abduh sebagai seorang pemikir Muslim rasional cenderung mengagungkan akal dan membolehkan ijtihad. Sementara kaum tradisonalis, yang umumnya orang-orang tua, cenderung menutup pintu ijtihad dan memilih taklid (lebih memilih teks ketimbang akal). Perbedaan paradigma, rasionalitas (modernis) dan tekstualis (tradisionalis) telah melahirkan produk pemikiran keagamaan yang berbeda, yaitu boleh dan tidaknya ijtihad. Namun K.H Machfud Shiddiq, seorang pemimpin Nahdatul Ulama (dalam dikotomi pemikiran, NU merupakan kaum tradisionalis) justru berpendapat berbeda dari para pemikir tradisonalis umunya, ia membolehkan ijtihad (Federspiel Howard M, 1996, p. 64) Pembolehan ijtihad oleh K.H Machfud merupakan suatu indikasi bahwa telah terjadi anomali atau persoalan yang ada tidak cukup dijawab hanya dengan paradigma lama, sehingga perlu paradigma baru yang mampu melahirkan jawaban-jawaban yang lebih memadai dengan membuka kembali pintu ijtihad agar lahir produk pemikiran keagamaan yang lebih relevan.

Contoh lainnya yang tak kalah menarik, misalnya tentang bentuk dan dasar negara pasca kemerdekaan. Polemik negara harus berdasarkan syariat Islam atau tidak (nasionalisme) telah mewarnai perdebatan pemikiran Islam di Indonesia. Perbedaan paradigma dalam melihat Islam dalam merumuskan negara merupakan salah satu bukti bahwa paradigma sangat berpengaruh terhadap produk pemikiran yang dilahirkannnya. Kelompok yang menginginkan Indonesia menjadi negara Islam merupakan corak pemikiran yang berdasarkan paradigma integralistik paradigma yang melihat kalau Islam tidak hanya mengatur persoalan moral, ritual ibadah, namun juga berkaitan dengan politik atau persoalan-persoalan yang berkaitan dengan negara. Berangkat dari paradigma tersebut melahirkan pemikiran bahwa Indonesia sebagai bangsa yang mayoritas Muslim sudah seharusnya menerapkan sistemsistem Islam, baik dalam bentuk maupun undang-undang negara (Federspiel Howard M, 1996, p. 112) 
Berdasarkan paradigma integralistik ini, upaya-upaya terhadap pelaksanaan syariat yang diakui secara kontitusional telah diperjuangkan oleh para pembesarpembesar Islam, meskipun pada akhirnya kandas di tengah jalan. Lahirnya Piagam Jakarta tanggal 22 juni 1945 merupakan puncak pertarungan konstitusional antara orang Muslim yang ingin mendirikan negara berdasarkan Islam dengan orang-orang nasionalis yang menolak bentuk negara Islam (kelompok ini sebagian besar juga orang-orang Islam) yang diketuai oleh Soekarno (Maarif, 1995, p. 163)

Berbeda dengan paradigma integralistik, paradigma nasionalis (tokoh utamanya Soekarno yang juga seorang Muslim) melihat bahwa Indonesia tidaklah cocok untuk menerapkan sistem Islam karena Indonesia terdiri dari masyarakat yang majemuk, tidak hanya Islam. Oleh karena itu, menjadikan Indonesia sebagai negara Islam adalah tindakan tidak adil dan sangat mungkin menimbulkan perpecahan. Dari paradigma ini melahirkan konsep negara nasionalis yang merupakan kompromi logis (Federspiel Howard M, 1996, p. 111) bagi terbentuknya negara yang terdiri dari berbagai agama, adat, dan suku yang beragam. Nasionalisme bagi Seokarno merupakan semacam bentuk keyakinan dan kesadaran bahwa rakyat itu satu golongan, satu bangsa (Maarif, 2019, p. 179) Namun demikian, orang-orang yang pro nasionalis seperti Soekarno, Hatta, dkk. bukan berarti ia telah mengenyampingkan Islam. Dalam banyak literatur, Hatta, misalnya, dikenal sebagai orang yang sangat taat. Perbedaan pandangan terhadap bentuk negara Indonesia nasionalisme atau Islamis - tidak lain karena perbedaan paradigma yang digunakan oleh tokoh-tokoh bangsa tersebut.

Pertarungan gagasan mengenai bentuk negara pasca kemerdekaan jika mengacu pada teori Kuhn merupakan pertarungan antar paradigma sebelum menjadi paradigma umum atau normal sains. Jika dilihat secara historis, pertarungan yang terjadi antara kelompok agamis (dengan konsep syariatnya) dan nasionalis (dengan nasionalismenya) merupakan pertarungan yang tak sepenuhnya dimenangkan oleh pihak tertentu. Dengan kata lain, meskipun pada akhirnya bentuk negara merupakan bentuk yang mengusung nasionalisme, tetapi nilai-nilai keislaman di dalamnya sangat jelas mengiringinya. Artinya, paradigma yang disepakati atau normal sains dalam bahasa Kuhn, adalah paradigma simbiotik: Paradigma antara agama dan negara saling membutuhkan dan mempengaruhi. Dari paradigma ini lahir pancasila sebagai dasar negara Indonesia.

Penting untuk digaris bawahi, paradigma tidak berbicara mana yang paling benar dan sahih, akan tetapi mana yang paling memungkinkan menjawab persoalan dan mendapat kesepakatan lebih banyak dalam masyarakat. Pendeknya, segala produk pemikiran/keilmuan termasuk pemikiran Islam di Indonesia - ditentukan oleh paradigmanya. Paradigma kapan saja 
bisa berubah dan berganti sebagaimana contoh-contoh yang sudah dijelaskan di atas. Dan dari waktu ke waktu, sejarah telah mencatat selalu ada pembaharuan terhadap pemikiran Islam (Madjid, 2019, p. 65) Artinya, menganggap produk keilmuan Islam yang lahir dari paradigma tertentu sebagai hasil akhir dan absolut merupakan sikap yang tergesa-gesa dan mengahmbat perkembangan dari pemikiran Islam itu sendiri.

Kegiatan ilmu pengetahuan selamanya bersifat historis, lantaran dibangun, dirancang dan dirumuskan oleh akal budi manusia yang juga bersifat historis. Yang dimaksud dengan historis di sini adalah terikat oleh ruang dan waktu, terpengaruh oleh perkembangan pemikiran dan perkembangan kehidupan sosial. Dengan begitu, artinya sangat memungkinkan terjadinya perubahan, pergeseran, perbaikan dan perumusan kembali serta penyempurnaan terhadap epistemologi keilmuan (Abdullah, 1996, p. 102)

Konsep paradigma dan revolusi Thomas Kuhn yang sudah dijelaskan di atas, dapat kita gunakan dalam keilmuan Islam di Indonesia guna membuka kembali keran pemikiran keislaman untuk melahirkan paradigma-paradigma baru yang lebih cocok terhadap permasalahan mutakhir yang dihadapi oleh umat. Apa yang dipaparkan oleh Kuhn tentang anomali adalah bagaimana kita harus sadar dan peka terhadap perkembangan zaman dan persoalan yang ada. Karena hanya dengan kepekaan, anomali bisa ditemukan, kemudian krisis, dan revolusi (lahirnya paradigma baru) - yang membuat pemikiran Islam di Indonesia menjadi dinamis, tidak statis. Tanpa kepekaan (kemampuan berpikir yang mendalam) dan kemampuan mencipta (melahirkan gagasan-gagasan/paradigma baru) sangat sulit bagi pemikiran Islam di Indonesia punya peran dan masa depan yang cerah. Sebab, pada masa yang akan datang, Islam akan dihadapkan pada persoalan kemanusiaan yang semakin rumit (Maarif, 2019a, p. 155)

\section{Kesimpulan}

Sejarah - khususnya sejarah ilmu - punya kedudukan penting dalam pemikiran Thomas Kuhn. Melalui sejarah ilmu, Kuhn menemukan bahwa perkembangan ilmu pengetahuan tidak ditentukan dengan jalan akumulasi atau falsifikasi, melainkan dengan pergeseran paradigma (revolusi sains). Paradigma, menurut Kuhn sangat penting bagi ilmuwan karena paradigma merupakan pola atau cara pandang yang sangat mempengaruhi langkah dan hasil dari suatu penelitian.

Meskipun Kuhn tidak berbicara keilmuan dalam ranah Islam, akan tetapi konsep paradigma dan revolusi sainsnya ternyata bisa diaplikasikan dalam keilmuan Islam, khusunya di Indonesia. Dengan berpijak pada paradigma dan revolusi, keilmuan Islam di Indonesia tidak akan berjalan di tempat, ia akan terus tumbuh dengan lahirnya pemikiranpemikiran keislaman yang lebih segar dan sesuai kebutuhan zaman. 


\section{Daftar Kepustakaan}

Abdullah, A. (1996) Studi Agama: Normativitas atau Historisitas. Yogyakarta: Pustaka Pelajar.

Alifah Putri, F. and Iskandar, W. (2020) 'Paradigma Thomas Kuhn: Revolusi Ilmu Pengetahuan dan Pendidikan', Nizhamiyah, 10(2), p. 6.

Asrudin, A. (2017) 'Thomas Kuhn dan Teori Hubungan Internasional: Realisme sebagai Paradigma', Global South Review, 1(2), p. 107. doi: 10.22146/globalsouth.28830.

Bertens, K. (2017) Ringkasan Sejarah Filsafat. 28th edn. Yogyakarta: Kanisius.

Effendi, R. (2020) 'Revolusi Ilmiah Thomas Kuhn: Perubahan Paradigma dan Implikasi dalam Bangunan Ilmu Keislaman', TAJDID : Jurnal Ilmu Keislaman dan Ushuluddin, 23(1), pp. 47-61.

Federspiel Howard M (1996) Persatuan Islam: Pembaharuan Islam Indonesia Abad XX. Edited by terj. Yudian W. asmin dan Afandi Mochtar. Yogyakarta: Gadja Mada University Press.

Kuhn, T. S. (1957) The Copernican Revolution: Planetary Astronomy in the Development of Western Thought. Amerika: Harvard University Press.

(1970) The Structure of Scientific revolutions. Chicago: Chicago Press.
(1977) The Essential Tension: Selected Studies in Scientific Tradition and Change. Chicago: Chicago Press.

Latif, M. (2014) Filsafat Ilmu: Orientasi ke Arah Pemahaman. Jakarta: Prenadamedia Group.

Maarif, A. S. (1995) Peta Bumi Intelektualisme Islam di Indonesia. Bandung: Mizan.

(2019a) Membumikan Islam: dari Romantisme Masa Silam Menuju Masa Depan. Edited by M. S. Ardani. Yogyakarta: IRCiSoD.

(2019b) Mencari Autentisitas dalam Dinamika Zaman. Edited by R. J. Antoni and R. Kurniawan. Yogyakarta: IRCiSoD.

Madjid, N. (2019) Khazanah Intelektual Islam. 2nd edn. Edited by N. Madjid. Jakarta: Yayasan Pustaka Obor.

Muslih, M. (2004) Filsafat Ilmu: Kajian atas Asumsi Dasar, Paradigma dan Kerangka Teori Ilmu Pengetahuan. Yogyakarta: Blukar.

Mustansyir, R. and Munir, M. (2013) FIlsafat Ilmu. Yogyakarta: Pustaka Pelajar.

Nurkhalis (2012) 'Kostruksi Teori Paradigma Thomas Kuhn', islam futur, XI(2).

Sudrajat et al. (2019) 'Epistemologi Thomas S. Kuhn Dan 
Munculnya Ilmu Pengetahuan Sosial', JISPINDO, 6(1), pp. 25-45.

Sumarna, C. (2016) Filsafat Pengetahuan. Bandung:

Remaja Rosdakarya.

Ulya, Inayatul dan Nushan, A. (2015)
'Pemikiran Thomas Kuhn dan Relevansinya Terhadap Keilmuan Islam', Fikrah, 3(2).

Zubaedi (2007) Filsafat Barat: Dari Logika Baru Rene Descartes hingga Revolusi Sains ala Thomas Kuhn. Yogyakarta: Ar-Ruzz Media Group. 